\title{
11. CLAY MINERALS AND THEIR DIAGENESIS IN CARBONATE-RICH SEDIMENTS (LEG 101, SITES 626 AND 627) 1
}

\author{
Holger Hüggenberg ${ }^{2}$ and Hans Füchtbauer ${ }^{2}$
}

\begin{abstract}
The insoluble residues of samples from ODP Sites 626 and 627 can be subdivided into four groups: (1) illite, $7 \AA$ minerals, quartz and feldspar; (2) smectite and zeolite (clinoptilolite); (3) palygorskite and in places sepiolite; and (4) glauconite and pyrite. Whereas group 1 is clearly terrigenous and group 4 authigenic, group 2 is most probably authigenic, as indicated by its abundance in samples with small insoluble residues and its appearance in SEM photographs. Group 3 is authigenic in Albian peritidal dolomite and possibly terrigenous in middle Miocene slumps and debris flows. Smectite crystallinity increases with age. This increase, however, is less pronounced in the Bahamian carbonate-rich samples than in the carbonate-poor silts south of Guatemala (DSDP Leg 84, Sites 569 and 570, the only comparable investigation) as far as can be judged from such a small number of samples.
\end{abstract}

\section{INTRODUCTION}

This investigation compared the clay-mineral composition and diagenetic alteration, as shown by downhole changes, of deep-sea sediments that were either rich or poor in carbonates. Thirty-two samples were studied from ODP Leg 101 Sites 626 (Straits of Florida; water depth $846 \mathrm{~m}$ ) and 627 (north of the Little Bahama Bank; water depth $1028 \mathrm{~m}$ ) (Shipboard Scientific Party, 1986a, 1986b). Unfortunately these samples were, with one exception (palygorskite-rich Sample 101-627B-17X-1, 5-7 $\mathrm{cm})$, very rich in carbonate, so that comparison of carbonaterich and carbonate-poor samples of the same area was impossible. The samples were therefore compared with samples from a carbonate-poor Pacific sequence offshore of Guatemala that were investigated by Helm (1985). We used Helm's procedure, which he developed to investigate very small diagenetic alterations of smectite and which had shown significant diagenetic changes with depth of the smectite crystallinity in the muds.

\section{METHODS}

We received carbonate samples of $30-\mathrm{cm}^{3}$ size and marl samples of $2-5-\mathrm{cm}^{3}$ size. Grain-size distribution of the bulk samples $(<2 \mu \mathrm{m}, 2-$ $63 \mu \mathrm{m},>63 \mu \mathrm{m}$ ) was recorded by Atterberg cylinders. X-ray analyses of smear slides of the bulk samples were made to obtain an overview of the different minerals present (Table 1), which in part were also identified under the microscope. Carbonate minerals were then X-rayed in the $<2-\mu \mathrm{m}$ and 2-63 $\mu \mathrm{m}$ fractions (Philips device PW 1050/25 with $2.2 \mathrm{KW}$ long-focus $\mathrm{Cu}$ valve with $\mathrm{Ni}$ filter). The material was ground by a mortar and filled in a $0.1-\mathrm{mm} \mathrm{Al}$ cuvette and recorded from $2^{\circ}$ to $45^{\circ} 2 \theta$ at $1 / 2^{\circ} / \mathrm{min}$, tc $4,2-1 \cdot 10^{2} \mathrm{cps}, 10-\mathrm{mm} / \mathrm{min}$ paper velocity, slit width $1^{\circ}$. The calcite/aragonite and calcite/dolomite ratios were measured using the areas of the X-ray peaks. Excess magnesium of calcite and excess calcium and ordering degree of dolomite were determined. Total carbonate content of the samples was determined by Scheibler (gasometric) analysis. These figures are more reliable than the figures recorded as "insoluble residues" after the acid treatment (Table 1). After unsuccessful attempts to concentrate the clay minerals by fractionation $(<2 \mu \mathrm{m})$, the bulk samples were treated with $10 \%$ unbuffered acetic acid at $70^{\circ} \mathrm{C}$ for less than $4 \mathrm{hr}$.

As it was impossible to fractionate the small insoluble residues, they were ground in a mortar and pipetted onto a glass for settling and drying. These texture slides were X-rayed before and after glycolization as

\footnotetext{
${ }^{1}$ Austin, J. A., Jr., Schlager, W., et al., 1988. Proc. ODP, Sci. Results, 101: College Station, TX (Ocean Drilling Program).

2 Institut für Geologie, Ruhr-Universität Bochum, Postfach 102148, 4630 Bochum 1, Federal Republic of Germany.
}

well as after heating to $375^{\circ}$ and $500^{\circ} \mathrm{C}$ between $2^{\circ}$ and $25^{\circ} 2 \theta$ at $1 / 2 \%$ $\mathrm{min}$, tc $4,4 \cdot 10^{2}, 5-\mathrm{mm} / \mathrm{min}$ paper velocity, $1 / 2^{\circ}$ slit width. Semiquantitative analyses of clay minerals (Table 2 ) were carried out according to Biscaye (1965). Kaolinite and chlorite generally could not be separated. The following correction factors were used for the peak areas: $7 \AA$ minerals, 0.5 ; illite, 1.0 ; smectite, 0.25 ; palygorskite, 0.33 ; sepiolite, 1.0 . The clay minerals were then normalized to $100 \%$. Palygorskite was identified by the main peak at $10.5 \AA$ and its shift to $10.0 \AA$ upon heating to $500^{\circ} \mathrm{C}$, whereas sepiolite was identified by the main peak at $12.5 \AA$, which decreased in intensity after heating to $500^{\circ} \mathrm{C}$; at the same time, a peak at $7.6 \AA$ appeared. Smectite crystallinity was defined as the ratio of peak height $(a)$ and peak width at half height $(p)$, according to Helm (1985) (see Fig. 3, C, right). Clay-mineral morphology and composition were investigated by SEM and EDX, respectively.

\section{RESULTS}

The results are grouped according to the stratigraphic units defined by the Shipboard Scientific Party (1986a, 1986b); depths are in meters below seafloor (mbsf).

Site 626: Unit I: 0-121.7 mbsf: foraminiferal-skeletal packstone and grainstone.

Unit II: 121.7-169.9 mbsf: clast-foraminiferal-skeletal floatstone.

Site 627: Unit IA: 0-108 mbsf: ooze with thin floatstones and minor packstones.

Unit IB: 108-144 mbsf: ooze with thin packstones; less micrite.

Unit IC: 144-181.4 mbsf: ooze with packstone.

(Unit I = "contemporary" carbonate-slope facies with turbidites, slumps, and debris flows.)

Unit II: 181.4-249 mbsf: (Not sampled.)

Unit III: 249-325 mbsf: calcareous ooze alternating with chalk (= oceanic-plateau chalks).

Unit IV: $325-344$ mbsf: (Not sampled.)

Unit V: $344-468$ mbsf: olive-gray marly calcareous ooze (=outershelf marls).

Unit VI: 468-536 mbsf: dolostone and gypsum (skeletal dolomitic limestone) (=very shallow-water platform).

\section{Site 626 (Fig. 1)}

\section{Units I and II}

According to grain-size analyses (Table 1), the samples are dominated by skeletal grains (foraminifers). The $<2-\mu \mathrm{m}$ fraction consists of aragonite needles and calcitic coccoliths, whereas the coarser fractions are low in aragonite. Traces of dolomite occur in all samples. The insoluble residue is very small and alternately dominated by quartz, clay minerals, and zeolite (determined by $\mathrm{X}$-ray and SEM to be clinoptilolite). Smectite is the only clay mineral (except for traces of palygorskite) in Unit II, whereas il- 
Table 1. Analyses of bulk samples from Sites 626 and 627 .

\begin{tabular}{|c|c|c|c|c|c|c|c|c|c|c|c|c|c|c|c|c|}
\hline \multirow[b]{2}{*}{$\begin{array}{l}\text { Sample (Leg 101) } \\
\text { (interval in cm) }\end{array}$} & \multirow[b]{2}{*}{$\begin{array}{l}\text { Depth } \\
\text { (mbsf) }\end{array}$} & \multirow[b]{2}{*}{ Unit } & \multicolumn{3}{|c|}{ Grain size } & \multirow{2}{*}{$\begin{array}{l}\text { Insoluble } \\
\text { residues } \\
\text { (\%) }\end{array}$} & \multirow{2}{*}{$\begin{array}{l}\text { Total } \\
\text { carbon- } \\
\text { ate (\%) }\end{array}$} & \multicolumn{9}{|c|}{ Mineralogy (not including clay minerals) ${ }^{\mathrm{a}}$} \\
\hline & & & $\begin{array}{c}<2 \mu \mathrm{m} \\
(\%)\end{array}$ & $\begin{array}{c}2-63 \mu \mathrm{m} \\
(\%)\end{array}$ & $\begin{array}{c}>63 \mu \mathrm{m} \\
(\%)\end{array}$ & & & $\begin{array}{l}\text { Cal- } \\
\text { cite }\end{array}$ & $\begin{array}{l}\text { Dolo- } \\
\text { mite }\end{array}$ & $\begin{array}{l}\text { Arag- } \\
\text { onite }\end{array}$ & Quartz & $\begin{array}{l}\text { Zeo- } \\
\text { lite }^{b}\end{array}$ & $\begin{array}{l}\text { Amphi- } \\
\text { bole }^{c}\end{array}$ & $\begin{array}{l}\text { Feld- } \\
\text { spard }^{\text {d }}\end{array}$ & Gypsum & Pyrite \\
\hline $626 \mathrm{~B}-4 \mathrm{R}-4,110-115$ & 143.3 & II & 12 & 24 & 64 & $<1$ & 91 & + & + & + & + & + & - & - & - & + \\
\hline $626 \mathrm{C}-4 \mathrm{X}-1,110-115$ & 31.1 & & 3 & 7 & 90 & 3 & 78 & + & + & + & + & + & - & + & + & + \\
\hline $626 C-6 \mathrm{X}-1,60-64$ & 45.3 & I & 1 & 7 & 92 & 1 & 99 & + & + & + & + & + & - & + & - & + \\
\hline $626 \mathrm{C}-13 \mathrm{H}-4,30-35$ & 116.9 & & 9 & 30 & 61 & 1 & 94 & + & + & + & + & + & - & + & - & + \\
\hline $626 \mathrm{C}-14 \mathrm{H}-2,132-133$ & 124.5 & & 12 & 33 & 55 & - & 91 & + & + & + & + & O & 0 & $\mathrm{O}$ & 0 & + \\
\hline $626 \mathrm{C}-14 \mathrm{H}-4,116-121$ & 127.3 & II & 5 & 27 & 68 & $<1$ & 98 & + & + & + & + & + & - & + & + & + \\
\hline $626 \mathrm{C}-16 \mathrm{H}-4,114-118$ & 146.4 & & 5 & 25 & 70 & $<1$ & 97 & + & + & + & + & + & - & + & + & + \\
\hline $627 \mathrm{~A}-1 \mathrm{H}-3,69-70$ & 3.7 & IA & 28 & 66 & 6 & 26 & 69 & + & + & - & + & - & + & + & - & + \\
\hline $627 \mathrm{~A}-1 \mathrm{H}-4,58-59$ & 5.1 & & 43 & 56 & 1 & - & 56 & + & + & - & + & - & + & + & - & + \\
\hline 627B-1H-3, 19-20 & 3.2 & & 32 & 58 & 10 & 26 & 69 & + & + & - & + & - & - & + & - & + \\
\hline 627B-1H-4, 5-6 & 4.5 & & 42 & 57 & 1 & - & 55 & + & + & - & + & - & + & + & - & + \\
\hline $627 \mathrm{~B}-2 \mathrm{H}-4,110-114$ & 11.4 & & 1 & 80 & 19 & 2 & 93 & + & + & + & + & + & + & + & - & + \\
\hline $627 \mathrm{~B}-4 \mathrm{H}-4,110-115$ & 30.8 & IA & 3 & 58 & 39 & 7 & 89 & + & + & + & + & + & + & + & - & + \\
\hline $627 \mathrm{~B}-6 \mathrm{H}-4,110-115$ & 49.8 & & 14 & 30 & 56 & 1 & 90 & + & + & + & + & + & + & + & - & + \\
\hline $627 \mathrm{~B}-8 \mathrm{H}-4,117-122$ & 78.6 & & 28 & 65 & 7 & 2 & 83 & + & + & + & + & + & - & + & - & + \\
\hline $627 \mathrm{~B}-10 \mathrm{H}-7,33-34$ & 91.8 & & 21 & 67 & 12 & - & 86 & + & $?$ & + & + & 0 & 0 & O & - & + \\
\hline $627 \mathrm{~B}-12 \mathrm{H}-5,56-57$ & 108.1 & & 19 & 66 & 15 & - & 87 & + & + & + & + & 0 & 0 & 0 & - & + \\
\hline $627 \mathrm{~B}-14 \mathrm{H}-2,132-133$ & 123.6 & IB & 33 & 48 & 19 & - & 69 & + & + & + & + & 0 & 0 & 0 & - & + \\
\hline $627 \mathrm{~B}-16 \mathrm{H}-6,9-11$ & 147.5 & & 30 & 46 & 24 & 10 & 78 & + & - & - & + & + & - & + & - & + \\
\hline $627 \mathrm{~B}-17 \mathrm{X}-1,5-7$ & 149.8 & IC & 71 & 26 & 3 & 65 & 6 & + & + & - & + & - & - & + & + & + \\
\hline $627 \mathrm{~B}-28 \mathrm{X}-4,110-115$ & 263.8 & & 35 & 51 & 14 & 6 & 83 & + & - & + & + & + & - & + & - & + \\
\hline 627B-29X-5, 111-113 & 275.1 & III & 42 & 53 & 5 & - & 80 & + & + & - & + & + & 0 & 0 & - & + \\
\hline $627 \mathrm{~B}-34 \mathrm{X}-4,120-125$ & 320.7 & & 2 & 95 & 3 & 2 & 84 & + & - & - & + & - & - & + & - & + \\
\hline $627 \mathrm{~B}-38 \mathrm{X}-4,75-80$ & 361.8 & & 38 & 58 & 4 & 54 & 27 & + & + & - & + & - & + & + & + & + \\
\hline $627 \mathrm{~B}-40 \mathrm{X}-3,130-135$ & 377.0 & & 35 & 62 & 3 & 45 & 60 & + & + & - & + & - & + & + & + & + \\
\hline $627 \mathrm{~B}-41 \mathrm{X}-4,110-115$ & 388.0 & & 24 & 70 & 6 & 35 & 57 & + & + & - & + & - & $?$ & + & + & + \\
\hline $627 \mathrm{~B}-42 \mathrm{X}-4,110-115$ & 397.5 & & 33 & 64 & 3 & 36 & 57 & + & + & - & + & - & $?$ & + & + & + \\
\hline $627 \mathrm{~B}-43 \mathrm{X}-4,110-115$ & 407.1 & v & 35 & 61 & 4 & 29 & 65 & + & + & - & + & - & $?$ & + & + & + \\
\hline $627 \mathrm{~B}-47 \mathrm{X}-6,57-62$ & 447.8 & & 34 & 52 & 14 & 41 & 50 & + & + & - & + & - & - & + & + & + \\
\hline $627 \mathrm{~B}-49 \mathrm{X}-1,13-15$ & 458.4 & & 21 & 55 & 24 & 18 & 82 & + & $?$ & - & + & - & - & + & + & + \\
\hline $627 \mathrm{~B}-49 \mathrm{X}-1,23-25$ & 458.5 & & 27 & 66 & 7 & 31 & 81 & + & $?$ & - & + & - & - & + & + & + \\
\hline 627B-51X, CC, 26-28 & 487.3 & VI & 4 & 58 & 38 & $<1$ & 95 & + & + & - & + & - & - & $?$ & - & - \\
\hline
\end{tabular}

a $+=$ present $-=$ absent; $O=$ not treated with acid; ? = identification uncertain.

Clinoptilolite.

c Hastingsite.

d Potassium feldspar and plagioclase including albite and anorthite.

lite and $7 \AA$ minerals are as common as smectite in Unit I (Table 2), most of which is of Quaternary age.

\section{Site 627 (Fig. 2)}

\section{Unit IA}

The uppermost samples (Quaternary; Tables 1 and 2) are marly muds (55\%-70\% carbonate) poor in coarse carbonate particles. Aragonite is absent; traces of dolomite are present. The clay minerals consist of illite and $7 \AA$ minerals; smectite is nearly absent. The lower samples of Unit IA (upper Miocene to Quaternary) are ooze with little insoluble residue (83\%-93\% carbonate); the bulk grain size is coarser than in the uppermost samples. Smectite is present in considerable amounts, and the samples also contain amphibole.

\section{Unit IB}

The only sample from this unit was poorly investigated because of technical problems. Besides the carbonates, only quartz and pyrite were identified.

\section{Unit IC}

Samples 101-627B-16H-6, 9-11 cm, and 101-627B-17X-1, 5-7 cm, are dark ooze and clay, respectively, which are different from the rest of Unit IC, a calcitic ooze with packstone. These two samples are unlike the samples above and below (Unit III) not only because of their high insoluble residues but also because of their composition (palygorskite, some smectite, quartz, and feldspar). Moreover, aragonite disappears in this unit.

\section{Unit III}

This unit is rich in silt- and clay-sized calcite and poor in insoluble residues. The clay-mineral fraction is dominated by smectite.

\section{Unit $\boldsymbol{V}$}

This marly section has a bulk grain-size distribution similar to that of Unit III, although the insoluble residues are increased compared with Unit III. Illite is more common than smectite, and $7 \AA$ minerals increase in the lower part.

\section{Unit VI}

This dolomite-gypsum sequence is represented by a dolomite sample $\left(\mathrm{Ca}_{0.55} \mathrm{Mg}_{0.45} \mathrm{CO}_{3}\right)$ with traces of calcite in the clay fraction. The insoluble residues $(<5 \%)$ consist of palygorskite, sepiolite, and quartz.

\section{DISCUSSION}

\section{Carbonates}

The most important constituent in carbonates is low-Mg calcite $\left(<4 \% \mathrm{MgCO}_{3}\right)$, comprising the coccoliths and foraminifers. The diagenetic behavior of the coccoliths from Site 627 can be outlined as follows: tiny parts of the coccoliths are usually dissolved in the uppermost layers, presumably owing to water depth (1028 m) at this site (i.e., below the zone of calcite saturation). In the sediment, however, cementation increases downhole, except for the marl (Unit V), in which clay hampers cementation and dissolution markedly increases. This occurrence 
Table 2. Clay-mineral distribution and relative percentages, Sites 626 and 627.

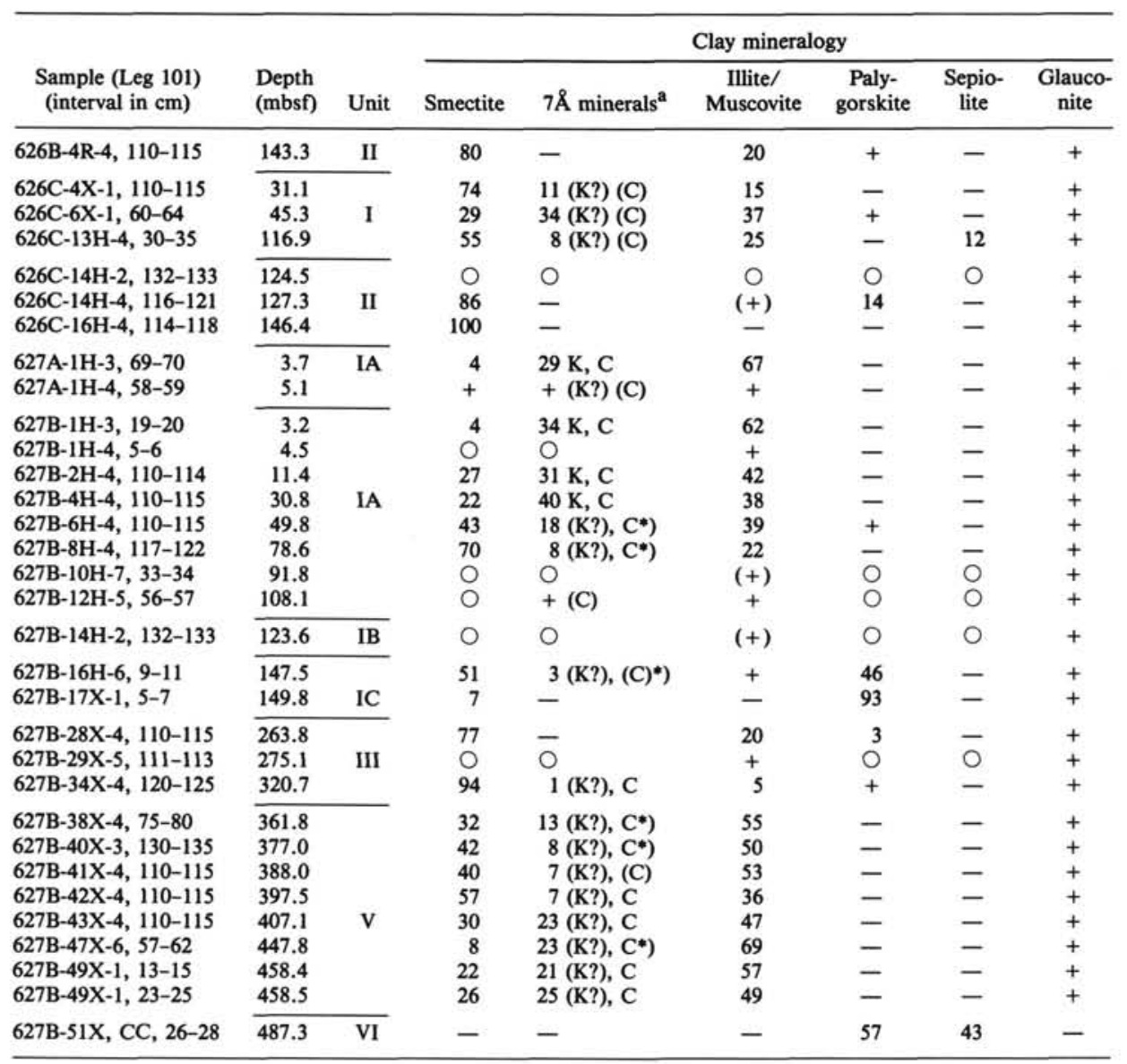

${ }^{\text {a }}$ Chlorite and kaolinite. $\mathrm{K}=$ kaolinite identified; $(\mathrm{K}$ ?) = kaolinite uncertain; $\mathrm{C}=$ chlorite identified; $(\mathrm{C})=$ chlorite uncertain; $C^{*}$ ) = swelling chlorite.

Note: $+=$ present; $-=$ absent $(+)=$ presence uncertain; $O=$ not treated with acid.

is normal (Brenneke, 1977) and is paralleled by an increased $\mathrm{Ca}^{2+}$ content of the interstitial water in the marl section.

The next most common carbonate mineral in these samples is aragonite, which forms clay-sized needles presumably derived from shallow-water green algae. Aragonite disappears between 150 and 250 mbsf.

Small quantities of dolomite rhombs $\left(\mathrm{Ca}_{0.51-0.58} \mathrm{Mg}_{0.49-0.42} \mathrm{CO}_{3}\right)$ are present in nearly all samples. Their size is about $5-50 \mu \mathrm{m}$. It is significant that these dolomite rhombs are more common $(10 \%-30 \%)$ in the intervals with high insoluble residues as also reported by Narkiewicz (1983) and less common $(<5 \%)$ in the intervals with small insoluble residues (a few percent). This does not apply to the deepest sample $\left(\mathrm{Ca}_{0.55} \mathrm{Mg}_{0.45} \mathrm{CO}_{3}\right)$ from the dolomite platform (Sample 101-627B-51X, CC, 26-28 cm), a 20 $40-\mu \mathrm{m}$ dolomite. There is no connection between dolomite content and $\mathrm{Mg}^{2+}$ and $\mathrm{SO}^{2-}$ in the interstitial water. The $\mathrm{SO}^{2-}$ concentrations approximate those of seawater throughout Hole 627B.

\section{Clay Minerals}

Results summarized in Table 2 show that the various clay minerals from Sites 626 and 627 have different origins. Although the small number of samples precludes definite conclusions, samples can be grouped into four categories of minerals with different characteristics: (1) illite, kaolinite and chlorite, quartz and feldspar; (2) smectite and zeolites; (3) palygorskite (and in places sepiolite); and (4) glauconite and pyrite. These occurrences are described as follows.
1. Illite, kaolinite, chlorite, quartz, and feldspar are the main terrigenous minerals in these samples. They are particularly enriched in marly Unit V. It may be significant that considerable quantities of terrigenous minerals occur only immediately above the postulated drowned Albian evaporitic platform. These terrigenous minerals may have been supplied from mainland Florida over the adjacent shelf, which may still have been shallow in Cenomanian time.

2. Smectite and zeolite (clinoptilolite) increase in calcite-rich samples. Smectite (Fig. 3) is the main clay mineral (more than $75 \%$ of the clay content) only in samples with more than $80 \%$ carbonate. This points to a nondetrital origin of smectite and clinoptilolite. The honeycomb shape of the smectite (as shown in Fig. 4) and the euhedral clinoptilolite laths suggest an in-situ origin, which is common in deep-sea sediments. Biogenic opal and possibly volcanic glass and feldspars may have contributed to the authigenic growth of smectite and clinoptilolite. Siliceous sponge spicules, which were found occasionally, show traces of leaching, in accordance with the $\mathrm{SiO}_{2}$ undersaturation of the interstitial water.

3. Palygorskite (and sepiolite) occur in a few samples only. Both samples from Subunit IC are dark layers picked out of a foraminifer-nannofossil packstone and floatstone. Sample 101$627 \mathrm{~B}-16 \mathrm{H}-6,9-11 \mathrm{~cm}$, contains $78 \%$ carbonate and equal amounts of smectite and palygorskite, whereas Sample 101-627B$17 \mathrm{X}-1,5-7 \mathrm{~cm}$, is presumably the "dark clay layer... present at the top of Core 101-627B-17X, which may be the result of alter- 

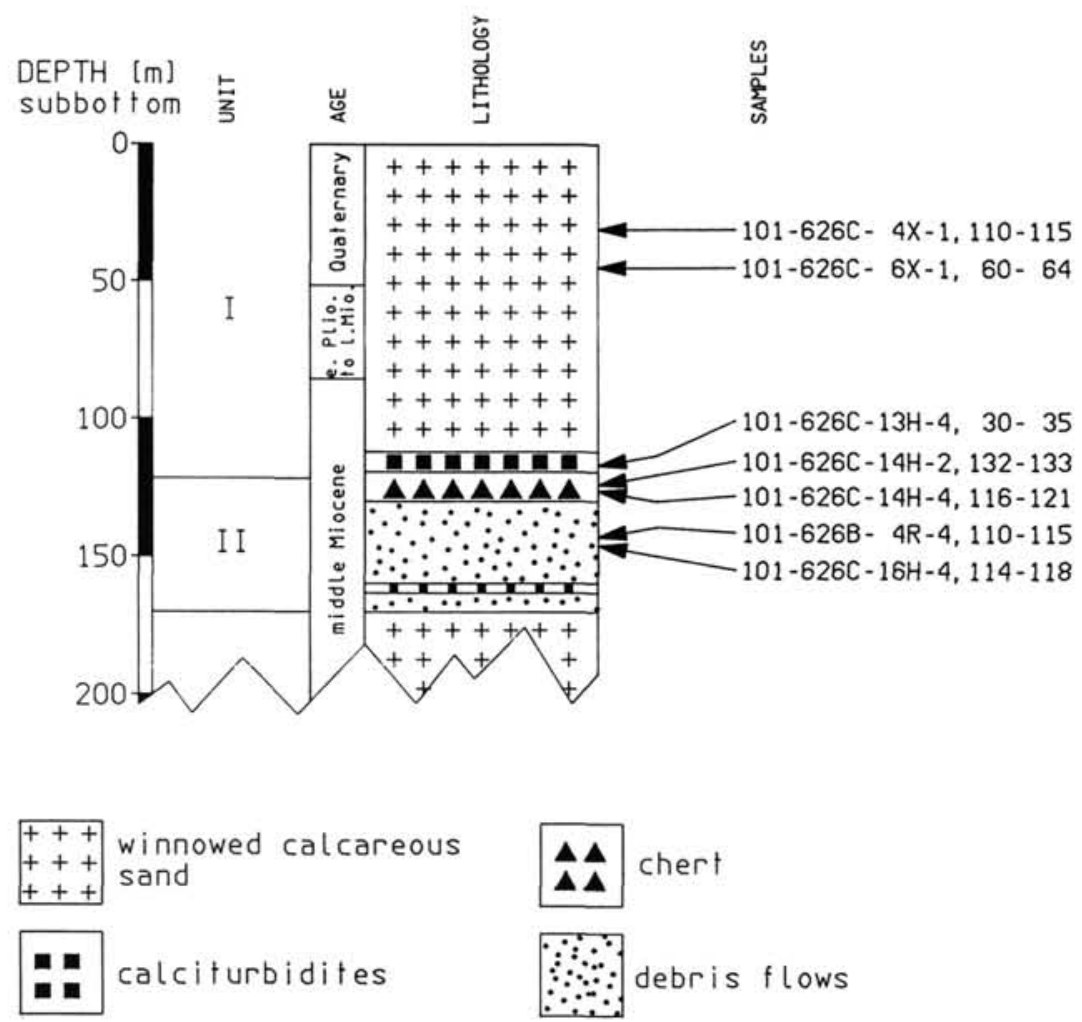

m calciturbidites

debris flows

Figure 1. Lithologic column for Site 626, Straits of Florida (based on Shipboard Scientific Party, 1986a). Stratigraphic positions of samples shown; sample intervals in centimeters.

ation of volcanic glass" (Shipboard Scientific Party, 1986b, p. 121). This sample contains only $6 \%$ carbonate, and palygorskite makes up $93 \%$ of the clay minerals. SEM photographs show a disordered aggregate of needles. In a sequence of deepwater marine calcareous muds containing smectite, kaolinite, chlorite, and illite as main clay minerals, these palygorskite samples are rather erratic. The interpretation of "a compound gravity-flow facies" in Subunit IC (Shipboard Scientific Party, 1986b, p. 126) points to an upslope origin, possibly by reworking of terrestrial material. According to Weaver (1984), lagoonal, brackish, and lacustrine palygorskite-sepiolite clays were reworked during middle Miocene time (i.e., during deposition of Subunit IC) in northern Florida, Georgia, and South Carolina and also on the Blake Plateau. We suggest that the palygorskite was derived as clay slabs either from the Blake Plateau or from another place of similar composition. This possibility agrees with the normal origin of palygorskite in slightly evaporitic, calcareous lacustrine environments (Millot, 1964), although palygorskite also forms in calcretes and dolocretes (Millot et al., 1969; Truc et al., 1987). In marine sediments, palygorskite is reported from epicontinental embayments of mainly Paleocene and Eocene age (i.e., periods of extensive and strong weathering) (Millot, 1964 , p. 315 ), sometimes with phosphates. But in such occurrences, its distribution is probably not as episodic as in the present profile. Moreover, Subunit IC represents an oceanic environment with high accumulation rates; it contains no phosphates. Sample 101-627B-51X, CC (26-28 cm), the other occurrence of palygorskite (together with sepiolite), is a calcareous and gypsiferous dolomite of late Albian age. It belongs to a very shallow-water, possibly supratidal platform (restricted environment) (Shipboard Scientific Party, 1986b, p. 125). The SEM (Fig. 5) shows authigenic growth of palygorskite and sepiolite on dolomite rhombs. They are probably authigenic.
4. Glauconite and pyrite occur in small quantities in all samples except Sample 101-627B-51X, CC, 26-28 (Table 2), which represents the peritidal platform. These minerals are in many cases casts of foraminifer chambers, which indicate their in-situ formation.

\section{Smectite Crystallinity}

A main objective of this investigation was ascertaining the early diagenesis of smectite before mixed-layer features developed. By quantifying the shape of the X-ray peaks, Helm (1985) demonstrated an increase of smectite crystallinity $a / p$ (see "Methods" chapter and the lower right diagram in Fig. 3) with age and, less significantly, with depth. Helm's samples, from DSDP Leg 84, Sites 569 and 570, on the Pacific continental slope off Guatemala, range from Pleistocene to Eocene in age and are carbonate-poor silts; they contain more $7 \AA$ minerals, plagioclase, and volcanic glass and less illite than do the ODP Leg 101 samples. Helm's results are compared with the results of the present investigation in the right of Figure 3. The Bahamian carbonate-rich samples show a smaller increase in smectite crystallinity with depth and age than do Helm's carbonate-poor Pacific samples. One sample (middle Campanian) shows a much higher crystallinity. Although Chamley (1979) used this as a criterion for terrigenous origin, the small number of samples examined here prohibits conclusions to be made concerning this sample.

\section{SUMMARY}

Investigation of 32 samples of calcareous muds and marls from Sites 626 (Straits of Florida) and 627 (north of Little Bahama Bank) yielded the following results. 


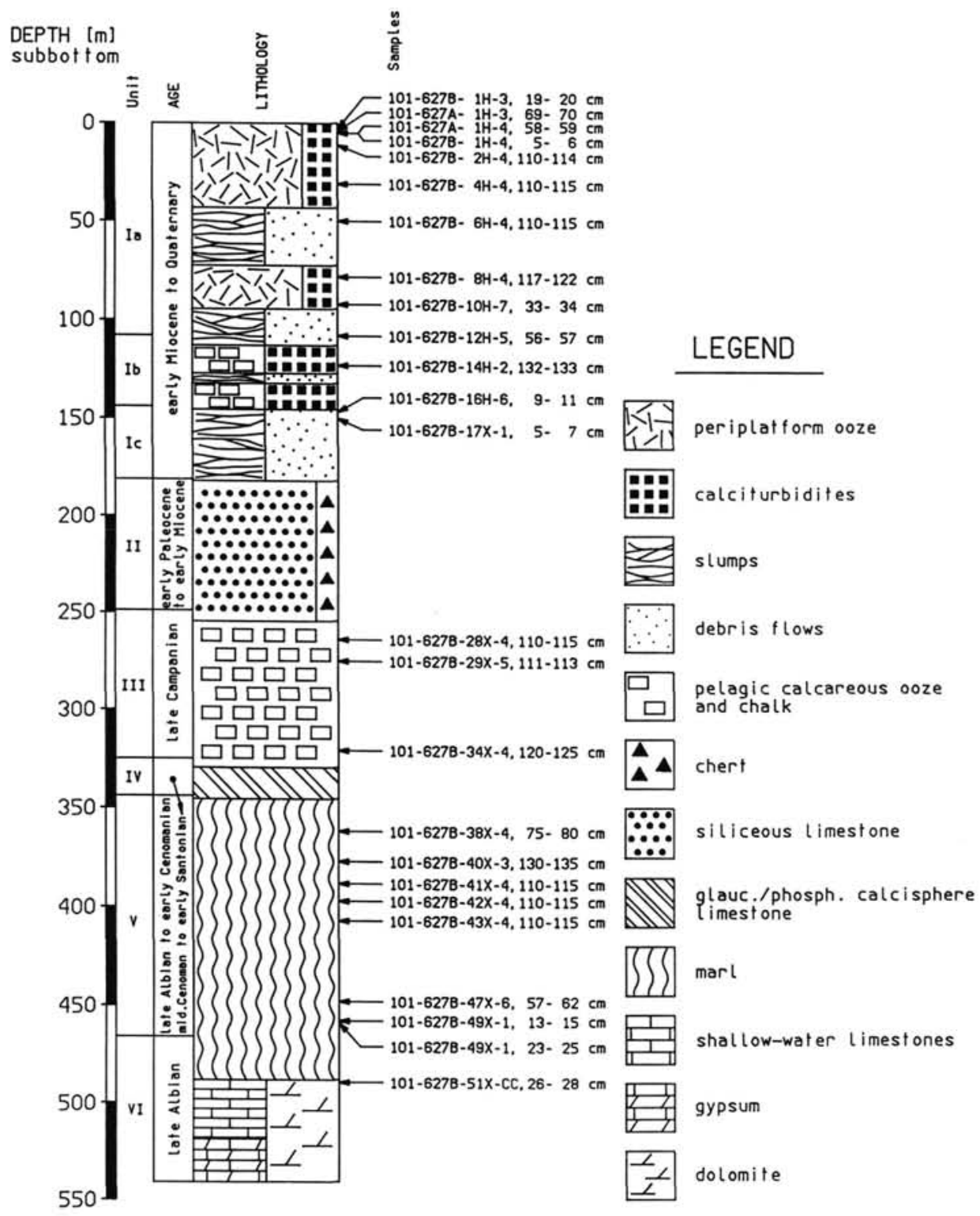

Figure 2. Lithologic column for Site 627, north of Little Bahama Bank (based on Shipboard Scientific Party, 1986b). Stratigraphic positions of samples shown; sample intervals in centimeters.

1. Calcitic cementation of coccoliths increases downhole, except for marls in which the coccoliths are sheltered by clay.

2. Aragonite disappears between 150 and $250 \mathrm{mbsf}$.

3. Dolomite occurs as dispersed rhombs, especially in intervals with high insoluble residues, and as a nearly pure dolomite in the upper Albian platform sequence.

4. Illite, kaolinite, chlorite, quartz, and feldspar are the main terrigenous minerals in these samples.

5. Palygorskite in the lower Miocene is presumably reworked from either the Blake Plateau or northern Florida, whereas it is formed in situ in the upper Albian dolomite-gypsum sequence.

6. Smectite and clinoptilolite are formed in situ.

7. Smectite crystallinity increases slightly with depth and age. This increase is lower than in carbonate-poor samples of the $\mathrm{Pa}$ cific continental slope off Guatemala.

\section{ACKNOWLEDGMENTS}

We thank R. Helm and D. Riedel for technical help and discussions and B. Kemper for typing the manuscript. Helpful suggestions by J. A.
Austin, Jr., D. Heling, A. A. Palmer, W. Schlager, and an anonymous referee are gratefully acknowledged.

\section{REFERENCES}

Biscaye, P., 1965. Mineralogy and sedimentation of recent deep sea clay in the Atlantic Ocean and adjacent seas and oceans. Geol. Soc. Am. Bull., 76:803-832.

Brenneke, J. C., 1977. A comparison of the stable oxygen and carbon isotope composition of Early Cretaceous and Late Jurassic carbonates from DSDP Sites 105 and 367. In Lancelot, Y., Seibold, E., et al., Init. Repts. DSDP, 41: Washington (U.S. Govt. Printing Office), 937-955.

Chamley, H., 1979. North Atlantic clay sedimentation and paleoenvironment since the Late Jurassic. In Talwani, M., Hay, W., and Ryan, W.B.F. (Eds.), Deep Drilling Results in the Atlantic Ocean: Continental Margins and Paleoenvironment: Washington (Am. Geophys. Union, Maurice Ewing Ser.), 343-360.

Helm, R., 1985. Mineralogy and diagenesis of slope sediments offshore Guatemala and Costa Rica, DSDP Leg 84. In von Huene, R., Aubouin, J., et al., Init. Repts. DSDP, 84: Washington (U.S. Govt. Printing Office), 571-594. 
Millot, G., 1964. Géologie des Argiles: Paris (Masson \& Cie).

Millot, G., Paquet, H., and Ruellan, A., 1969. Néoformation de l'attapulgite dans les sols à carapace calcaire de la Basse Monlonya (Maroc oriental). C.R. Acad. Sci., Paris, 268-D:2771-2774.

Narkiewicz, M., 1983. Dolomite from clay in argillaceous or shale-associated marine carbonates-discussion. J. Sediment. Petrol., 53:13531354.

Shipboard Scientific Party, 1986a. Site 626: Straits of Florida. In Austin, J. A., Jr., Schlager, W., et al., Proc. ODP, Init. Repts., 101: College Station, TX (Ocean Drilling Program), 49-81.

, 1986b. Site 627: southern Blake Plateau. In Austin, J. A., Jr., Schlager, W., et al., Proc. ODP, Init. Repts., 101: College Station, TX (Ocean Drilling Program), 111-158.
Truc, G., Triat, J.-M., Sassi, S., Paquet, H., and Millot, G., 1987. Caractères géneraux de l'épigénie carbonatée de surface, par alteration météorique liée à la pédogenèse, et par altération sous couverture liée à la diagenèse. Excursion guideb., 8th Reg. Mtg. Internat. Assoc. Sedimentol., Tunis, 100-107.

Weaver, C. E., 1984. Origin and geological implications of the palygorskite deposits of S.E. United States. In Singer, A., and Galan, G. (Eds.), Palygorskite-Sepiolite, Occurrences, Genesis and Uses: Amsterdam (Elsevier, Dev. Sedimentol.), 37:39-58.

Date of initial receipt: 20 February 1987

Date of acceptance: 4 September 1987

Ms 101B-135

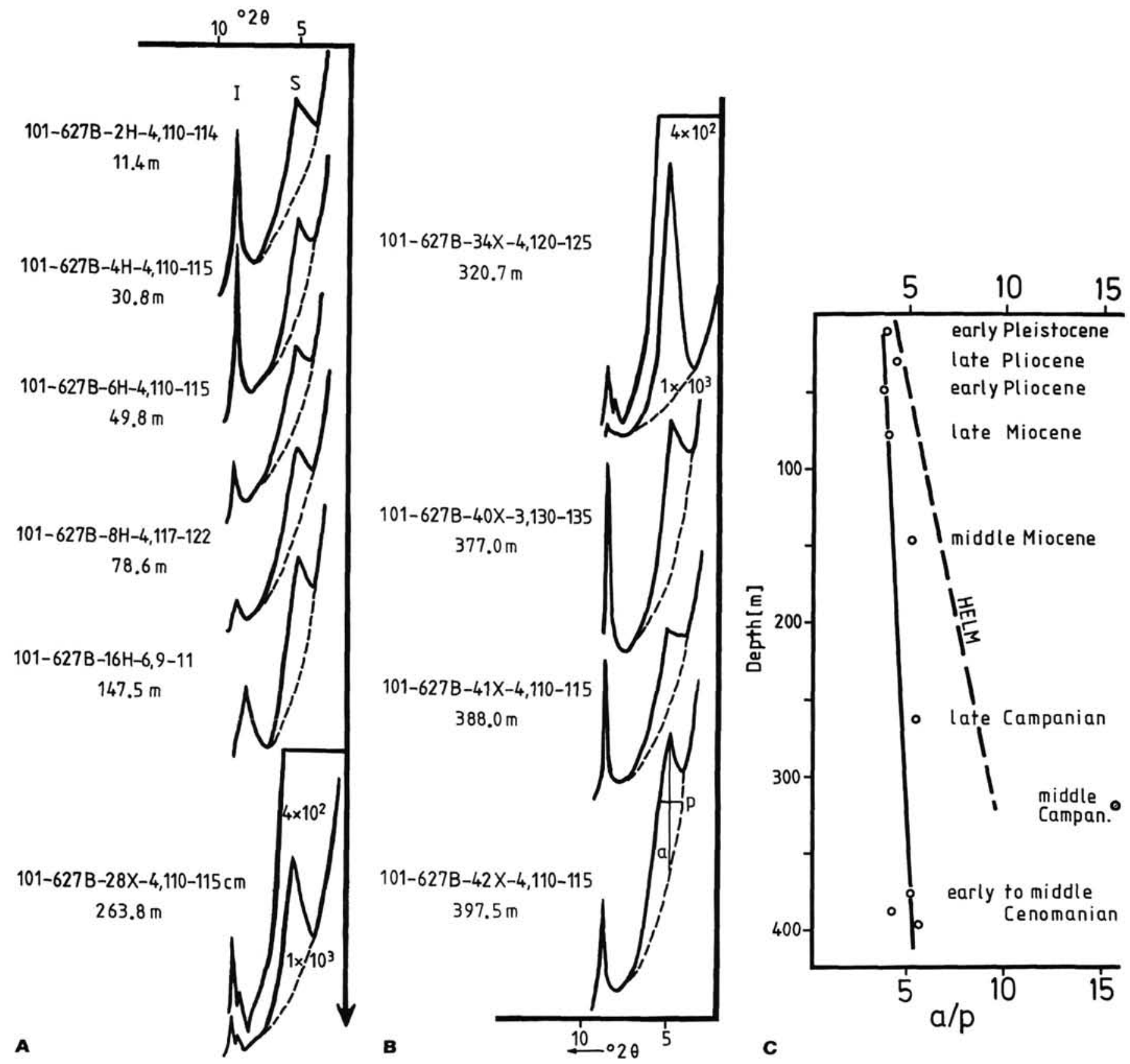

Figure 3. A and B. Illite $(I)$ and smectite $(S)$ peaks of 10 samples from Hole 627B. Sample intervals given in centimeters; sub-bottom depths indicated. C. At the right, the smectite crystallinity based on $a / p$ ratios (peak height/peak width at half height) of these Leg 101 samples is compared with the smectite crystallinity obtained by Helm (1985, Fig. 11, left) in carbonate-poor Pacific deep-sea sediments off Guatemala. 


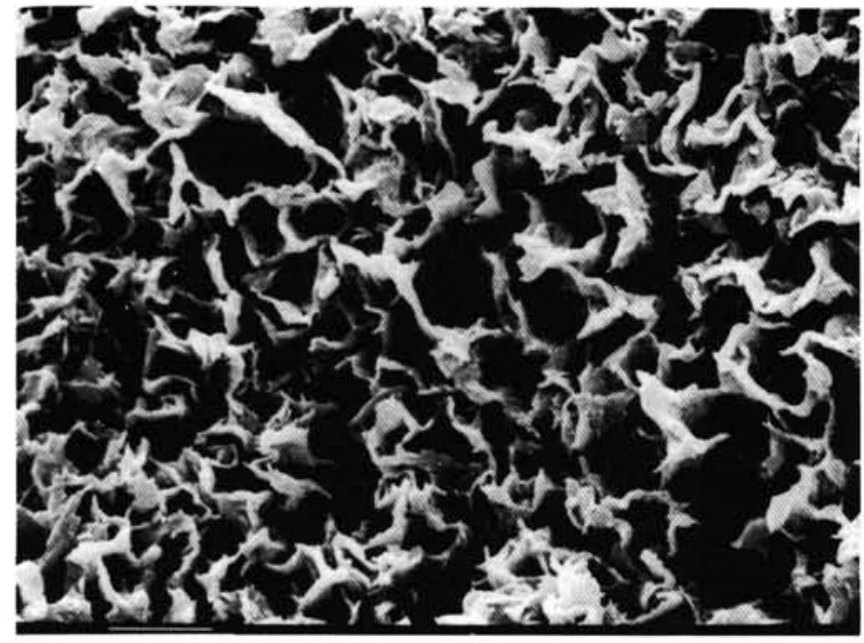

Figure 4. Honeycomb appearance of authigenic smectite. Sample 101$626 \mathrm{~B}-4 \mathrm{R}-4,110-115 \mathrm{~cm}$ (bar $=4 \mu \mathrm{m})$.

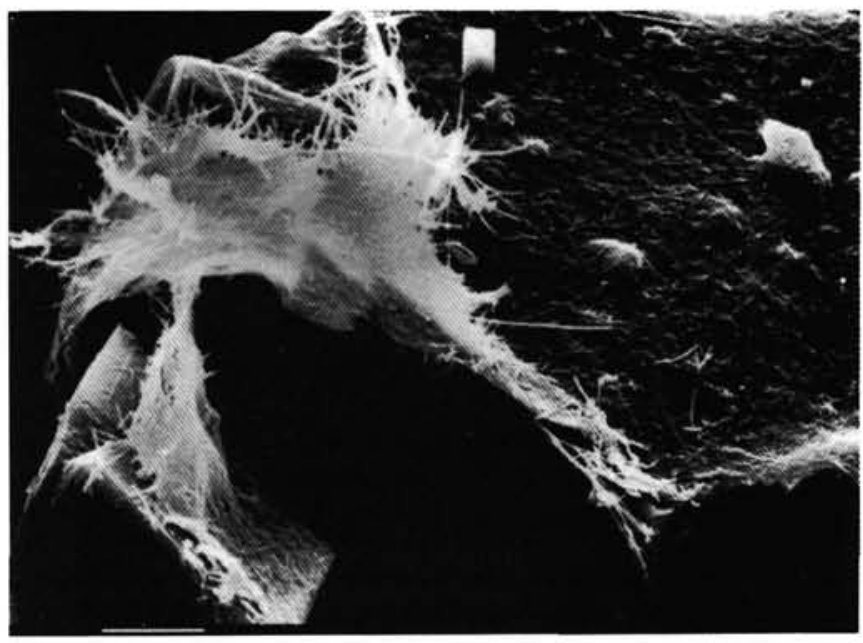

Figure 5. Palygorskite overgrowths on authigenic dolomite rhombohedra. Sample 101-627B-51X, CC, 26-28 cm (bar $=4 \mu \mathrm{m})$. 